\title{
GRHL2 wt Allele
}

National Cancer Institute

\section{Source}

National Cancer Institute. GRHL2 wt Allele. NCI Thesaurus. Code C162373.

Human GRHL2 wild-type allele is located in the vicinity of $8 \mathrm{q} 22.3$ and is approximately 186 $\mathrm{kb}$ in length. This allele, which encodes grainyhead-like protein 2 homolog protein, is involved in development and maintenance of epithelial tissues and neurulation. Mutation of the gene is associated with non-syndromic sensorineural deafness autosomal dominant type 28. 